\title{
OVERALL THERMAL PERFORMANCE OF FLEXIBLE PIPING UNDER SIMULATED BENDING CONDITIONS
}

\author{
J. E. Fesmire, ${ }^{a}$ S. D. Augustynowicz, ${ }^{b}$ and J. A. Demko ${ }^{c}$ \\ NASA Kennedy Space Center, YA-F2-T \\ Kennedy Space Center, Florida, 32899, USA \\ ${ }^{b}$ Dynacs Inc., DNX-3 \\ Kennedy Space Center, Florida, 32899, USA \\ ${ }^{c}$ Oak Ridge National Laboratory, USA
}

\begin{abstract}
Flexible, vacuum-insulated transfer lines for low-temperature applications have higher thermal losses than comparable rigid lines. Typical flexible piping construction uses corrugated tubes, inner and outer, with a multilayer insulation (MLI) system in the annular space. Experiments on vacuum insulation systems in a flexible geometry were conducted at the Cryogenics Test Laboratory of NASA Kennedy Space Center. The effects of bending were simulated by causing the inner tube to be eccentric with the outer tube. The effects of spacers were simulated in a controlled way by inserting spacer tubes for the length of the cylindrical test articles. Two material systems, standard MLI and a layered composite insulation (LCI), were tested under the full range of vacuum levels using a liquid nitrogen boiloff calorimeter to determine the apparent thermal conductivity ( $\mathrm{k}$-value). The results indicate that the flexible piping under simulated bending conditions significantly degrades the thermal performance of the insulation system. These data are compared to standard MLI for both straight and flexible piping configurations. The definition of an overall $\mathrm{k}$-value for actual field installations $\left(\mathrm{k}_{\mathrm{oafi}}\right)$ is described for use in design and analysis of cryogenic piping systems.
\end{abstract}




\section{INTRODUCTION}

Bending and bending-type mechanical effects come from four sources: bending, as in handling and installation; thermal contraction and expansion; line pressure reaction forces; and the weight of the line (sagging). Spacers are employed in the design of flexible lines to keep the inner line concentric within the outer line during manufacturing and to counteract these mechanical effects during operation. Spacers and the materials from which they are made must conduct as little heat as possible. The performance of MLI is known to be sensitive to the various localized compression effects and trapped residual gases produced by the overall mechanical influences of bending and spacers. The first part of the study, documented in the paper, Thermal Insulation Performance of Flexible Piping for Use in HTS Power Cables, which compares ideal MLI, MLI on rigid piping, and MLI between flexible piping in the concentric configuration, provides the basis for studying bending effects [1]. In this experimental research study, a section of insulated flexible piping was tested under cryogenic vacuum conditions including simulated bending and spacers.

\section{EXPERIMENTAL}

The test setup and methods used in this second part of the study were the same as those used in the previous part of the study on the concentric configuration without spacers or simulated bending $[1,2]$. The effect of spacers between the inner and outer corrugated pipes (or bellows) was simulated experimentally in two practical ways. In the first method (see FIGURE 1), five 6.4-millimeter- (mm) diameter plastic rings were placed circumferentially around an untouched MLI test article at a spacing interval of $102 \mathrm{~mm}$. The circumferential rings in this case, with MLI on a smooth sleeve, simulated discrete spacers. In a second approach (see FIGURE 2), three 19-mm-diameter G-10 tubes were inserted axially between the outer bellows and the outer surface of the insulation. This second case, with insulation between the bellows, simulated a continuous-type spacer design by the axially oriented tubes. The effect of bending (see FIGURE 3) was simulated by shifting the outer corrugated pipe relative to the (fixed) inner corrugated pipe for an eccentric configuration. The thicknesses, layer densities, and localized compression amounts for the seven different test articles are presented in TABLE 1. The gaps, major and minor, are defined as the available insulation space. Test series $\mathrm{C} 124$ (smooth sleeve), $\mathrm{C} 120, \mathrm{C} 128$, and $\mathrm{C} 132$ are the simulated spacer cases. Test series $\mathrm{C} 121, \mathrm{C} 129$, and $\mathrm{C} 133$ are the simulated bending, or eccentric, cases. 


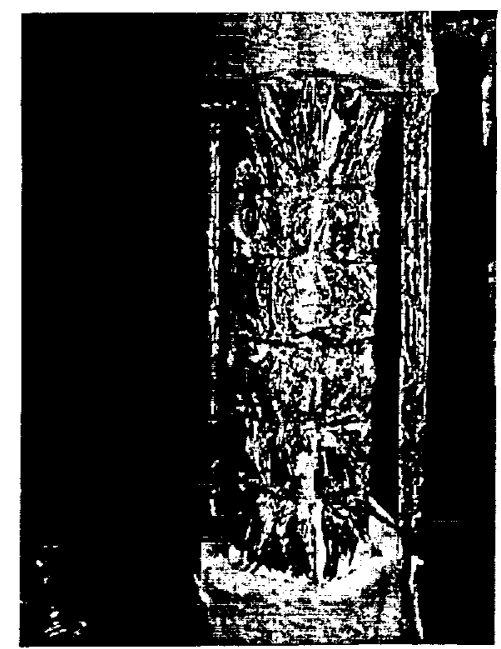

FIGURE 1. Simulated spacer configuration (circumferential rings).

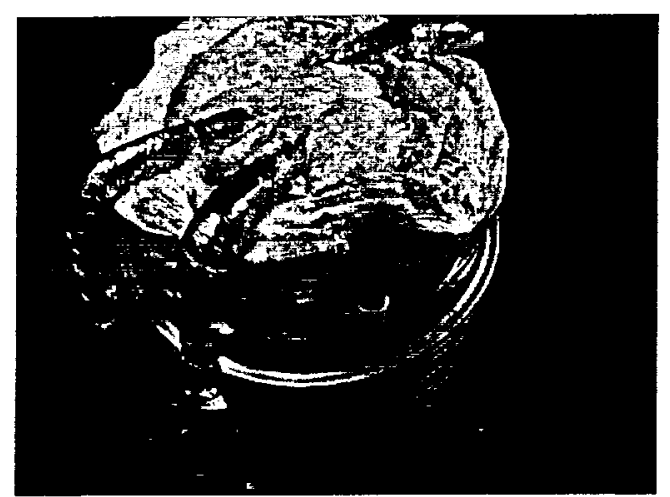

FIGURE 2. Simulated spacer configuration (axial tubes).

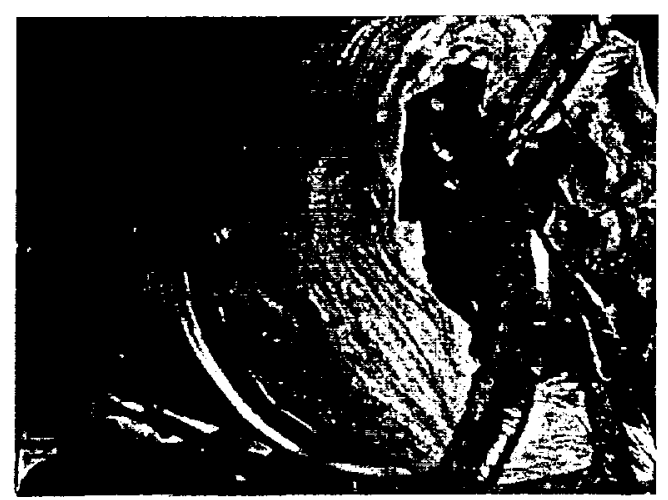




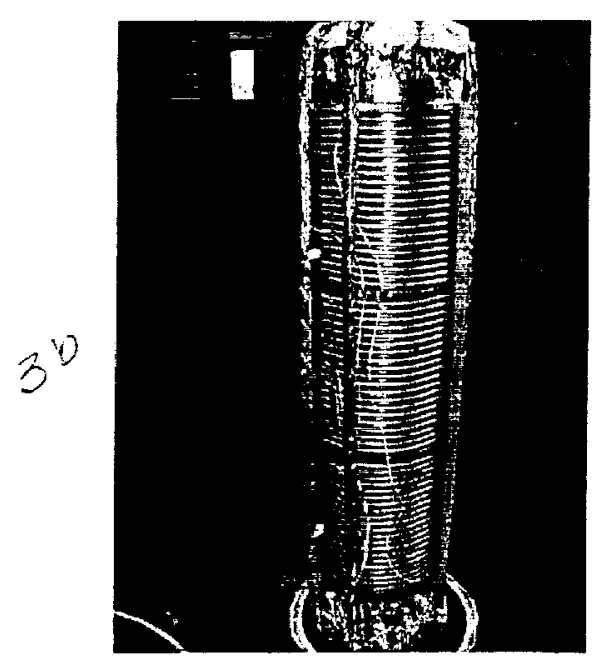

FIGURE 3. Simulated bending configuration (eccentric).

TABLE 1. Thicknesses, layer densities, and localized compression for insulation test articles.

\begin{tabular}{|c|c|c|c|c|c|c|}
\hline Test Series & $\begin{array}{l}\text { Nominal } \\
\text { Thickness } \\
\text { (mm) }\end{array}$ & $\begin{array}{c}\text { Nominal } \\
\text { Layer Density } \\
\text { (layers } / \mathrm{mm} \text { ) }\end{array}$ & $\begin{array}{l}\text { Major } \\
\text { Gap } \\
(\mathrm{mm})\end{array}$ & $\begin{array}{l}\text { Minor } \\
\text { Gap } \\
(\mathrm{mm})\end{array}$ & $\begin{array}{l}\text { Compressed } \\
\text { Local Density } \\
\text { (layers } / \mathrm{mm} \text { ) }\end{array}$ & $\begin{array}{c}\text { Percent } \\
\text { Compression }\end{array}$ \\
\hline $\begin{array}{c}\mathrm{C} 124, \text { smooth sleeve, } \\
60 \mathrm{MLI}+\text { rings }\end{array}$ & 24.5 & 2.4 & $\ldots$ & 7.2 & 8.4 & 71 \\
\hline $\begin{array}{l}\text { C120, corrugated, } \\
60 \mathrm{MLI}+\text { tubes }\end{array}$ & 23.8 & 2.5 & 27.0 & 8.0 & 7.5 & 66 \\
\hline $\begin{array}{l}\text { C 128, corrugated, } \\
30 \mathrm{LCI}+\text { tubes }\end{array}$ & 23.0 & 1.3 & 27.0 & 8.0 & 3.8 & 65 \\
\hline $\begin{array}{l}\text { C132, corrugated, } \\
60 \mathrm{MLI}+\text { tubes }\end{array}$ & 27.0 & 2.2 & 27.0 & 8.0 & 7.5 & 70 \\
\hline $\begin{array}{l}\text { C121, corrugated, } \\
60 \mathrm{MLI}+\text { eccentric }\end{array}$ & 23.8 & 2.5 & 47.0 & 7.0 & 8.6 & 71 \\
\hline $\begin{array}{l}\text { C129, corrugated, } \\
30 \text { LCI+eccentric }\end{array}$ & 23.0 & 1.3 & 44.5 & 9.5 & 3.2 & 59 \\
\hline $\begin{array}{l}\text { Cl33, corrugated, } \\
60 \mathrm{MLI}+\text { eccentric }\end{array}$ & 27.0 & 2.2 & 48.0 & 6.0 & 10.0 & 78 \\
\hline
\end{tabular}

\section{RESULTS AND DISCUSSION}

Over 50 tests of 7 thermal insulation systems were performed in this second part of the experimental research study. TABLE 2 reports the key measurements and conditions for the insulation test articles. Also listed, for reference purposes, are the test articles from the paper describing part one of this study [1]. Graphs of the apparent thermal conductivity as a function of cold vacuum pressure (CVP) are presented in FIGURES 4, 5, and 6. FIGURE 4 shows the results for the spacer simulation using circumferential tubes, while FIGURE 5 gives the results for the spacer simulation using axial tubes. FIGURE 6 shows the results for the bending simulation (eccentric configuration).

Spacers compress the MLI causing local increases in layer density. Compression was measured to be from 65 to 71 percent as listed in TABLE 1. The spacer simulations show a significant increase in the rate of heat transfer for the high-vacuum tests. For C124, the smooth sleeve MLI with the circumferential rings as spacers (see FIGURE 1), the k-value increased by 67 percent. For the corrugated piping with axial tubes as spacers (see FIG- 
URE 2), the heat transfer increased by similar amounts. The k-values for $\mathrm{C} 120, \mathrm{C} 132$, and C128 increased by 84 percent, 25 percent, and 135 percent, respectively. For the tests at soft-vacuum levels, the overall k-values were only slightly higher than the reference (concentric) cases because gaseous conduction is the dominant mode of heat transfer. The LCI performed about 3 times better in this range compared to the MLI types.

The simulated bending (eccentric) configuration gave compression on one side of the test article. The local increases in compression were measured to be from 59 to 78 percent as listed in TABLE 1. The bending simulations also showed a significant increase in the rate of heat transfer for the high-vacuum tests. For the corrugated piping in the eccentric configuration (see FIGURE 3), the heat transfer increased by roughly the same amounts as for the simulated spacer cases. The k-values for C121, C133, and C129 increased by 42 percent, 33 percent, and 100 percent, respectively. For the tests at soft-vacuum levels, the overall $k$-values were only slightly higher than the reference (concentric) cases. The LCI again performed with a much lower k-value in this range compared to the MLI types.

TABLE 2. Summary of measurements and conditions for insulation test articles.

\begin{tabular}{|c|c|c|c|c|c|c|c|}
\hline $\begin{array}{l}\text { Test } \\
\text { Series }\end{array}$ & $\begin{array}{l}\text { Description of } \\
\text { Insulation System }\end{array}$ & $\begin{array}{l}\text { Installed } \\
\text { Density } \\
\left(\mathrm{kg} / \mathrm{m}^{3}\right)\end{array}$ & $\begin{array}{c}\text { Total } \\
\text { Thickness } \\
(\mathrm{mm}) \\
\end{array}$ & $\begin{array}{c}\text { CVP } \\
\text { (millitorr) }\end{array}$ & $\begin{array}{c}\text { k-value } \\
(\mathrm{mW} / \mathrm{m}-\mathrm{K})\end{array}$ & $\begin{array}{l}\text { CBT } \\
(\mathrm{K})\end{array}$ & $\begin{array}{l}\text { WBT } \\
\text { (K) }\end{array}$ \\
\hline $\begin{array}{l}\mathrm{Cl08} \\
\text { (ref.) }\end{array}$ & $\begin{array}{l}\text { Smooth sleeve, MLI, alumi- } \\
\text { num foil and fiberglass paper, } \\
40 \text { layers, } 1.8 \text { layers } / \mathrm{mm}\end{array}$ & 58 & 22.3 & $\begin{array}{c}0.26 \\
10 \\
1000\end{array}$ & $\begin{array}{l}0.08 \\
0.49 \\
9.49 \\
\end{array}$ & $\begin{array}{l}87 \\
87 \\
92\end{array}$ & $\begin{array}{l}284 \\
281 \\
196 \\
\end{array}$ \\
\hline $\begin{array}{l}\mathrm{C} 123 \\
\text { (ref.) }\end{array}$ & $\begin{array}{l}\text { Smooth sleeve, } \text { MLI, alumi- } \\
\text { num foil and fiberglass paper, } \\
60 \text { layers, } 2.4 \text { layers } / \mathrm{mm}\end{array}$ & 79 & 24.5 & $\begin{array}{c}0.01 \\
10 \\
1000\end{array}$ & $\begin{array}{l}0.09 \\
0.48 \\
9.96 \\
\end{array}$ & $\begin{array}{l}86 \\
85 \\
87\end{array}$ & $\begin{array}{l}295 \\
290 \\
275\end{array}$ \\
\hline $\mathrm{C} 124$ & $\begin{array}{l}\text { Same as } \mathrm{Cl} 23 \text { but with } 5 \\
\text { each circumferential rings }\end{array}$ & 79 & 24.5 & $\begin{array}{c}0.05 \\
10 \\
1000\end{array}$ & $\begin{array}{l}0.15 \\
0.57 \\
11.5\end{array}$ & $\begin{array}{l}87 \\
85 \\
91 \\
\end{array}$ & $\begin{array}{l}296 \\
296 \\
271 \\
\end{array}$ \\
\hline $\begin{array}{l}\text { C119 } \\
\text { (ref.) }\end{array}$ & $\begin{array}{l}\text { Corrugated, MLI, aluminum } \\
\text { foil and fiberglass paper, } 60 \\
\text { layers, } 2.5 \text { layers } / \mathrm{mm}\end{array}$ & 82 & $\begin{array}{c}23.8 \\
27.0 \text { (gap) }\end{array}$ & $\begin{array}{c}0.01 \\
10 \\
1000 \\
\end{array}$ & $\begin{array}{l}0.19 \\
0.72 \\
8.49 \\
\end{array}$ & $\begin{array}{r}109 \\
90 \\
113\end{array}$ & $\begin{array}{l}295 \\
292 \\
294 \\
\end{array}$ \\
\hline $\mathrm{C} 120$ & $\begin{array}{l}\text { Same as C119 but with } 3 \\
\text { each axial tubes as spacers }\end{array}$ & 82 & $\begin{array}{c}23.8 \\
27.0 \text { (gap) } \\
\end{array}$ & $\begin{array}{c}0.05 \\
10 \\
1000\end{array}$ & $\begin{array}{l}0.35 \\
0.87 \\
10.3 \\
\end{array}$ & $\begin{array}{r}116 \\
90 \\
114 \\
\end{array}$ & $\begin{array}{l}292 \\
294 \\
293 \\
\end{array}$ \\
\hline $\mathrm{C} 121$ & $\begin{array}{l}\text { Same as } C 119 \text { but in eccen- } \\
\text { tric configuration }\end{array}$ & 82 & $\begin{array}{c}23.8 \\
27.0 \text { (gap) } \\
\end{array}$ & $\begin{array}{c}0.05 \\
9 \\
1000 \\
\end{array}$ & $\begin{array}{l}0.27 \\
0.76 \\
9.10 \\
\end{array}$ & $\begin{array}{r}113 \\
90 \\
112 \\
\end{array}$ & $\begin{array}{l}297 \\
297 \\
297 \\
\end{array}$ \\
\hline $\begin{array}{l}\text { C131 } \\
\text { (ref.) }\end{array}$ & $\begin{array}{l}\text { Corrugated, MLI, aluminum } \\
\text { foil and fiberglass paper, } 60 \\
\text { layers, } 2.2 \text { layers } / \mathrm{mm}\end{array}$ & 72 & $\begin{array}{c}27.0 \\
27.0 \text { (gap) } \\
\end{array}$ & $\begin{array}{c}0.01 \\
11 \\
1000\end{array}$ & $\begin{array}{l}0.12 \\
0.45 \\
8.06 \\
\end{array}$ & $\begin{array}{r}103 \\
90 \\
115 \\
\end{array}$ & $\begin{array}{l}297 \\
294 \\
295 \\
\end{array}$ \\
\hline $\mathrm{C} 132$ & $\begin{array}{l}\text { Same as C131 but with } 3 \\
\text { each axial tubes as spacers }\end{array}$ & 72 & $\begin{array}{c}27.0 \\
27.0 \text { (gap) }\end{array}$ & $\begin{array}{c}0.01 \\
10 \\
1000\end{array}$ & $\begin{array}{l}0.15 \\
0.62 \\
9.23 \\
\end{array}$ & $\begin{array}{r}108 \\
89 \\
112 \\
\end{array}$ & $\begin{array}{l}297 \\
294 \\
290 \\
\end{array}$ \\
\hline $\mathrm{C} 133$ & $\begin{array}{l}\text { Same as } C 131 \text { but in eccen- } \\
\text { tric configuration }\end{array}$ & 72 & $\begin{array}{c}27.0 \\
27.0 \text { (gap) }\end{array}$ & $\begin{array}{c}0.01 \\
10 \\
1000\end{array}$ & $\begin{array}{l}0.16 \\
0.61 \\
8.32 \\
\end{array}$ & $\begin{array}{r}113 \\
91 \\
110 \\
\end{array}$ & $\begin{array}{l}297 \\
296 \\
294\end{array}$ \\
\hline $\begin{array}{l}\mathrm{C} 127 \\
\text { (ref.) }\end{array}$ & $\begin{array}{l}\text { Corrugated, layered compos- } \\
\text { ite insulation, } 30 \text { layers }\end{array}$ & 78 & $\begin{array}{c}23.0 \\
27.0 \text { (gap) } \\
\end{array}$ & $\begin{array}{c}0.02 \\
11 \\
1000\end{array}$ & $\begin{array}{l}0.20 \\
0.59 \\
3.05 \\
\end{array}$ & $\begin{array}{r}117 \\
90 \\
98 \\
\end{array}$ & $\begin{array}{l}294 \\
292 \\
289 \\
\end{array}$ \\
\hline $\mathrm{C} 128$ & $\begin{array}{l}\text { Same as } \mathrm{C} 127 \text { but with } 3 \\
\text { each axial tubes as spacers }\end{array}$ & 78 & $\begin{array}{c}23.0 \\
27.0 \text { (gap) }\end{array}$ & $\begin{array}{c}0.02 \\
13 \\
1000 \\
\end{array}$ & $\begin{array}{l}0.47 \\
0.83 \\
3.30 \\
\end{array}$ & $\begin{array}{r}138 \\
92 \\
98 \\
\end{array}$ & $\begin{array}{l}296 \\
292 \\
294 \\
\end{array}$ \\
\hline $\mathrm{C} 129$ & $\begin{array}{l}\text { Same as } \mathrm{Cl} 27 \text { but in eccen- } \\
\text { tric configuration }\end{array}$ & 78 & $\begin{array}{c}23.0 \\
27.0 \text { (gap) }\end{array}$ & $\begin{array}{c}0.01 \\
5 \\
1000 \\
\end{array}$ & $\begin{array}{l}0.40 \\
0.50 \\
2.85\end{array}$ & $\begin{array}{r}134 \\
94 \\
98 \\
\end{array}$ & $\begin{array}{l}293 \\
294 \\
294 \\
\end{array}$ \\
\hline
\end{tabular}


$\mathrm{CVP}=$ cold vacuum pressure $\mathrm{CBT}=$ cold boundary temperature; $\mathrm{WBT}=$ warm boundary temperature; $\mathrm{kg} / \mathrm{m}^{3}=$ kilogram per cubic meter; $\mathrm{mW} / \mathrm{m}-\mathrm{K}=$ milliwatt per meter-kelvin; $\mathrm{K}=$ kelvin

FIGURE 4. Spacer simulation results (circumferential rings), variation of apparent thermal conductivity with CVP.

FIGURE 5. Spacer simulation results (axial tubes), variation of apparent thermal conductivity with CVP.

FIGURE 6. Bending simulation results (eccentric), variation of apparent thermal conductivity with CVP.

FIGURE 7. Summary of all results, variation of apparent thermal conductivity with CVP.

\section{OVERALL THERMAL PERFORMANCE $\left(k_{\text {oafi }}\right)$}

The nominal gap diameters (254-mm inside diameter of the outer and 200-mm outside diameter of the inner) of the basic concentric configuration of the inner and outer flexible pipes are used for all apparent thermal conductivity (k-value) calculations in this study. The use of these nominal diameters gives representative thermal performance for a flexible pipeline, such as a high-temperature superconducting (HTS) power cable, in an actual field installation. These diameters also provide a standardized way of comparing the thermal performance of different pipelines in different sizes.

The total insulation system includes the inner piping, the insulation material layers, the outer piping, and other items such as spacers and getters. Corrugation geometry, spacer design, manufacturing factors, vacuum maintenance, outgassing, insulation materials, layer 


$$
7 \text { is. } 4
$$

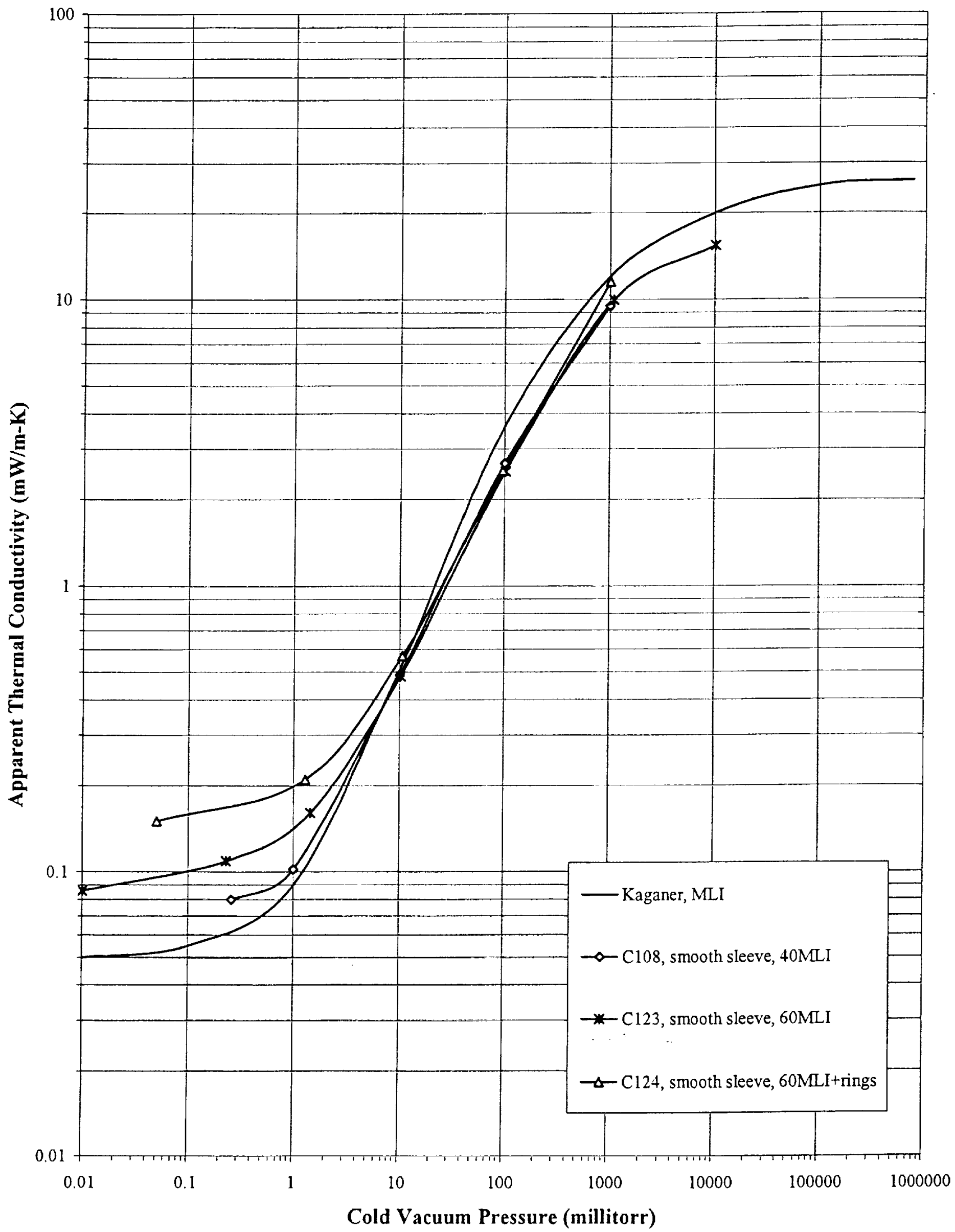


7ig. 5

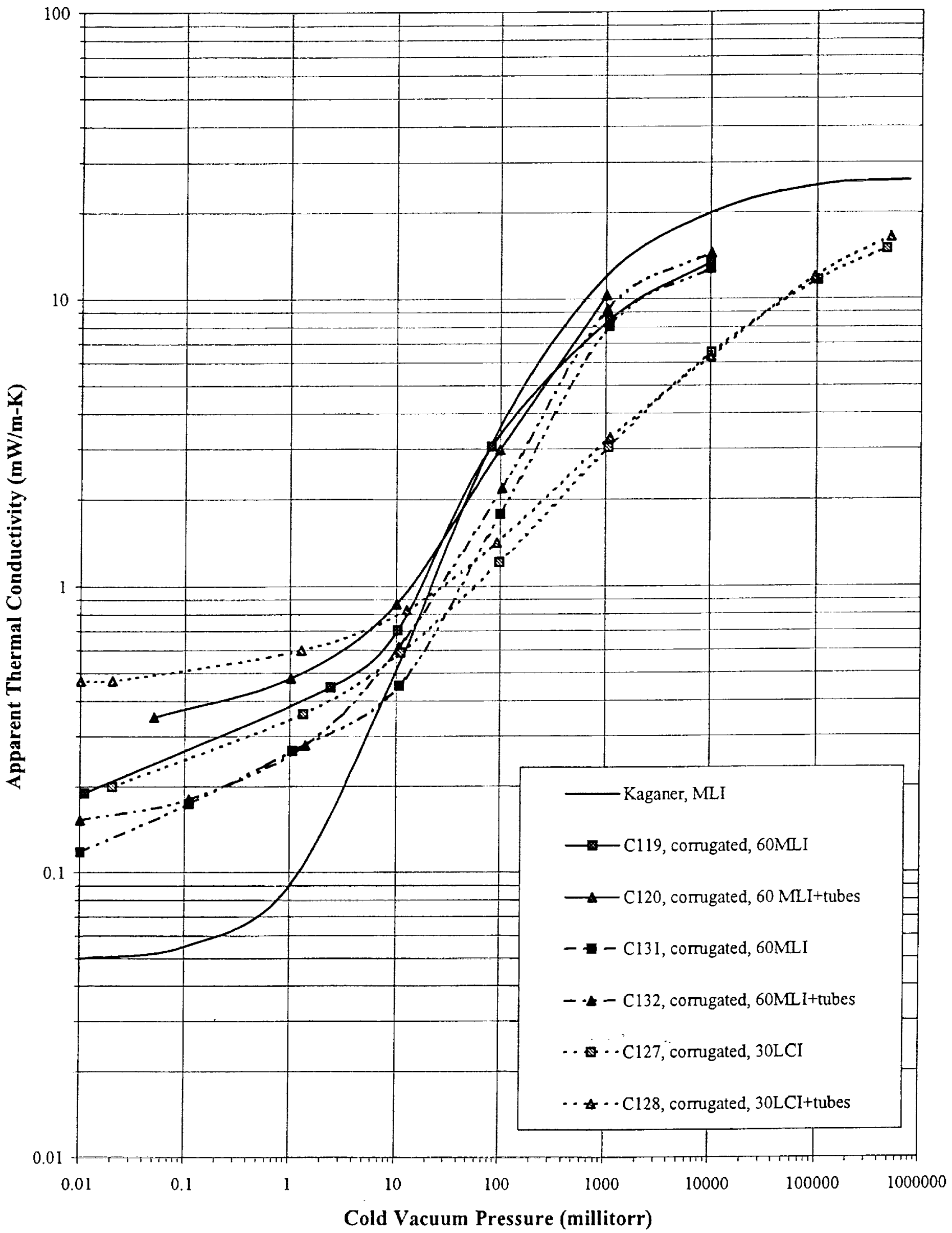


Fig. 6

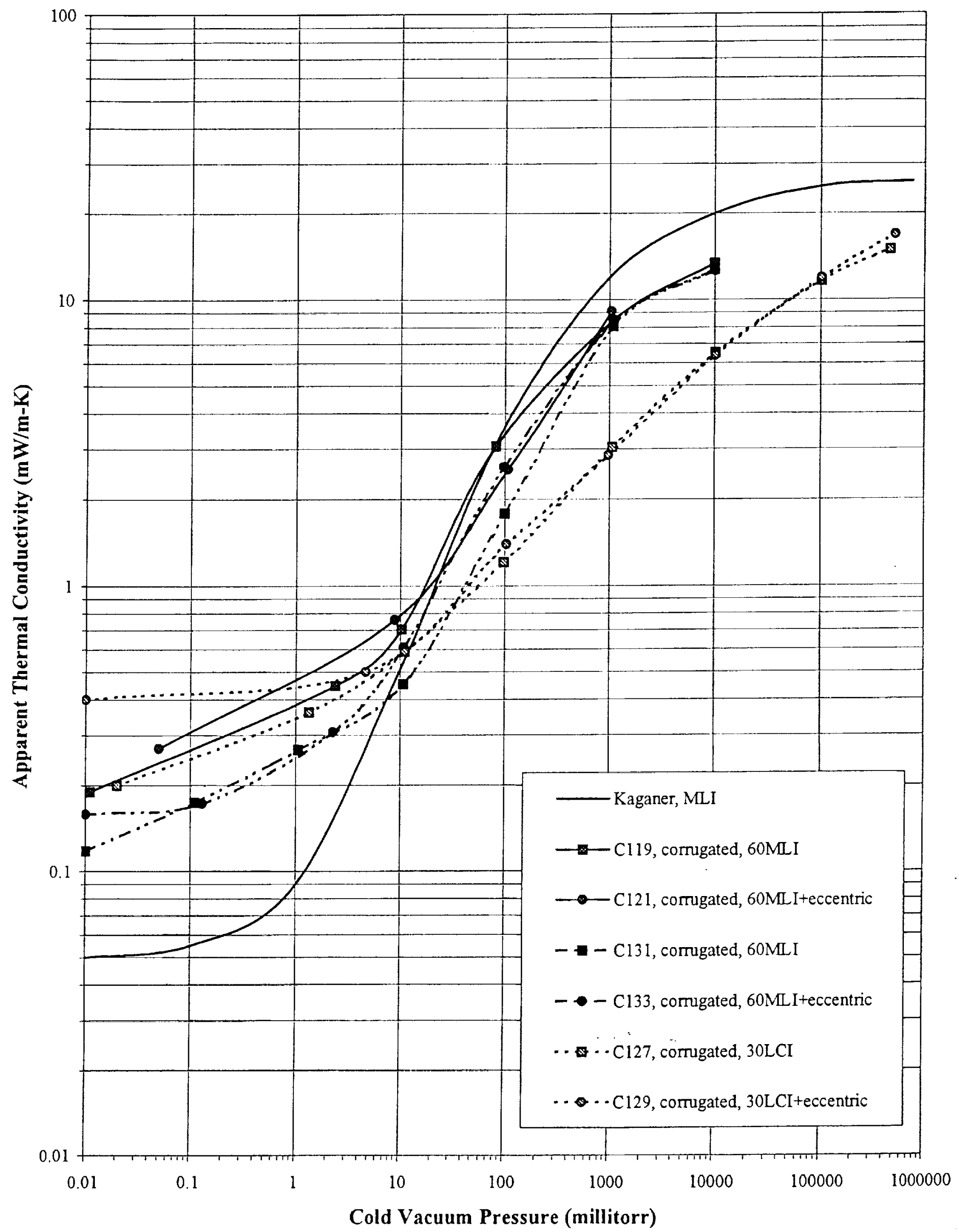


$7 \mathrm{ig} .7$

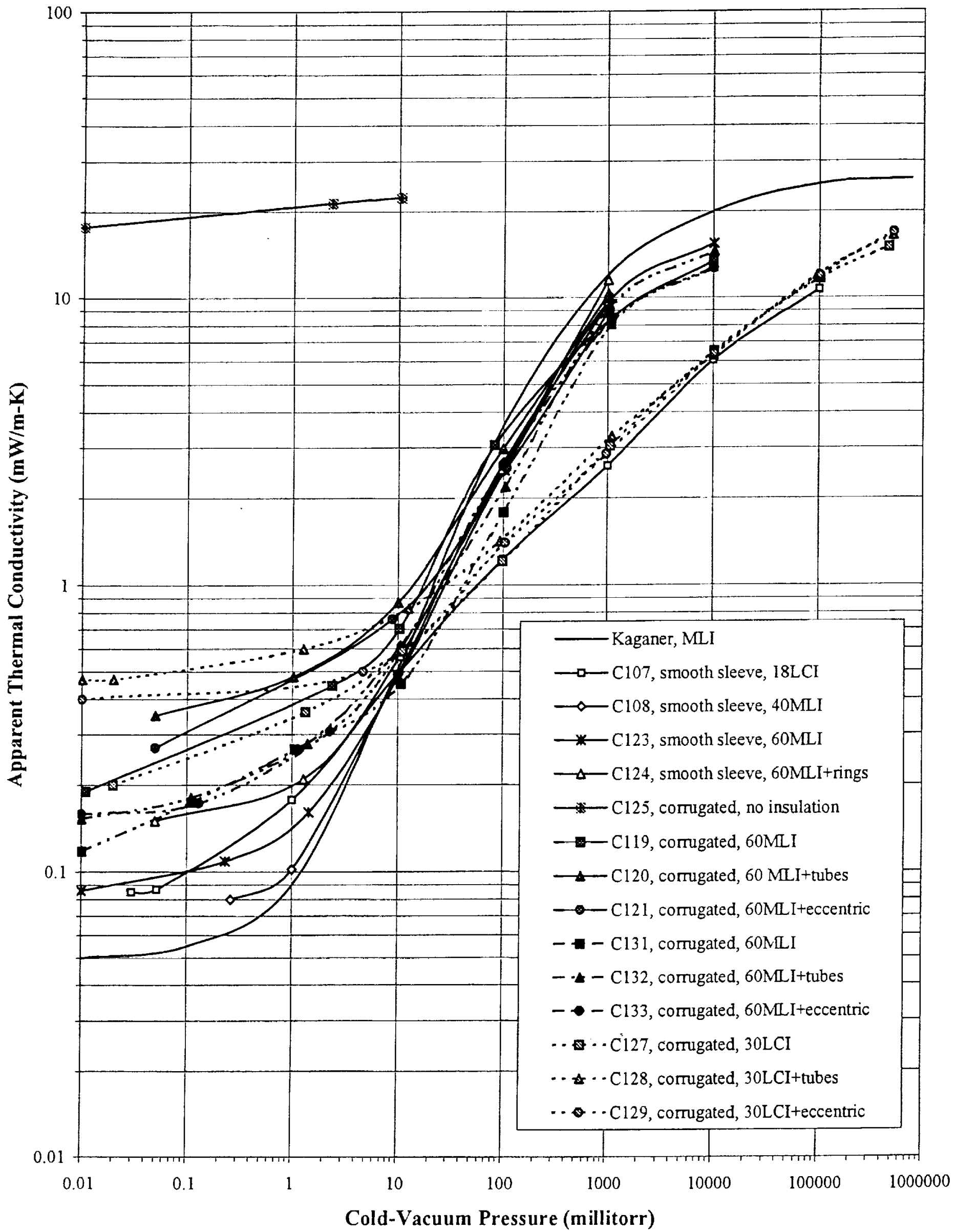


densities, and other factors all affect the overall thermal performance of a double-wall flexible piping system. Vendor data for vacuum-insulated piping are typically given in heat leak rate per unit length [watts per meter $(\mathrm{W} / \mathrm{m})$ ] and are useful then only for a specific diameter pipeline. An overall $k$-value for actual field installations $\left(\mathrm{k}_{\mathrm{oafi}}\right)$ is therefore proposed as a more generalized measure for thermal performance comparison and design calculation.

For example, from this study of a $200-\mathrm{mm}$ by $254-\mathrm{mm}$ double-wall flexible pipe with 60 layers MLI, we report an overall $\mathrm{k}$-value (at high vacuum with boundary temperatures of $295 \mathrm{~K}$ and $105 \mathrm{~K}$ ) of about $0.22 \mathrm{~mW} / \mathrm{m}-\mathrm{K}$. Now consider a $75-\mathrm{mm}$ by $125-\mathrm{mm}$-size line, operating at boundary temperatures of $300 \mathrm{~K}$ and $77 \mathrm{~K}$, which has been proposed for a single-phase HTS power cable [5]. The heat leak rate per unit length for this particular case can then be determined by equation (1):

$$
\frac{Q}{L}=2 \pi k_{\text {oafi }} \frac{\Delta T}{\ln \left(D_{o} / D_{i}\right)}=2.743 k_{\text {offi }}=0.60 \mathrm{~W} / \mathrm{m}
$$

This value can be compared with manufacturers' data for a 2- by 4-inch nominal pipe size (60- by $110-\mathrm{mm}$ actual size) line: $2.30 \mathrm{~W} / \mathrm{m}$ (flexible) and $0.75 \mathrm{~W} / \mathrm{m}$ (rigid) [6]. The overall k-value from this study is, of course, not an actual field installation, and therefore, the heat leak rate is, somewhat lower than the conservative vendor data. Converting these typical heat leak values into their thermal conductivity equivalents, we obtain $k_{\text {oafi }}$ of 0.99 $\mathrm{mW} / \mathrm{m}-\mathrm{K}$ (flexible) and $0.32 \mathrm{~mW} / \mathrm{m}-\mathrm{K}$ (rigid). The $\mathrm{k}_{\text {oafi }}$ also provides a direct correspondence to the $k$-values reported for insulation materials and illustrates the large difference between ideal MLI performance and the performance of actual systems with MLI.

\section{CONCLUSIONS}

In this experimental research study, a section of insulated flexible piping was tested under cryogenic vacuum conditions including simulated spacers and bending. This paper, on the thermal performance testing of flexible piping, is aimed at providing practical application information to persons in the field of superconducting power technology and related industries. An overall k-value for actual field installation $\left(\mathrm{k}_{\mathrm{oafi}}\right)$ has been defined for direct comparison of different types and different sizes of double-wall insulated piping. Seven different insulation systems were tested in this part of the study. The simulated spacers tests and the simulated bending tests showed, at high-vacuum conditions, significant degradation in the thermal performance of a given insulation system (typically greater than 50 percent). The system of LCI performed much better than the MLI types under soft-vacuum conditions.

We report a typical $\mathrm{k}$-value for these cases as $0.22 \mathrm{~mW} / \mathrm{m}-\mathrm{K}$, which is approaching one order of magnitude worse than ideal MLI $(0.05 \mathrm{~mW} / \mathrm{m}-\mathrm{K})$. Considering a $75-$ by $125-\mathrm{mm}-$ size line at boundary temperatures of $300 \mathrm{~K}$ and $77 \mathrm{~K}$, as proposed for a single-phase HTS power cable, the heat leak rate per unit length is then $0.60 \mathrm{~W} / \mathrm{m}$. This figure can be compared with vendor data of $2.30 \mathrm{~W} / \mathrm{m}$ (flexible) and $0.75 \mathrm{~W} / \mathrm{m}$ (rigid), corresponding to $k_{\text {oafi }}$ of $0.99 \mathrm{~mW} / \mathrm{m}-\mathrm{K}$ (flexible) and $0.32 \mathrm{~mW} / \mathrm{m}-\mathrm{K}$ (rigid). Further work should include cryostat tests of specific size insulation test articles and a long flexible line test. An 18 -m-long 
pipeline test apparatus is now in operation at the Cryogenics Test Laboratory for conducting liquid nitrogen thermal performance tests.

\section{ACKNOWLEDGEMENTS}

The authors thank Mr. Wayne Heckle and Mr. Zoltan Nagy of Dynacs Inc. for their assistance in performing the experiments.

This work was supported by the U.S. Department of Energy by interagency agreement DE-AI05-00OR22814 under the Superconductivity Partnership Initiative.

\section{REFERENCES}

1. J.E. Fesmire, S.D. Augustynowicz, and J.A. Demko, "Thermal Insulation Performance of Flexible Piping for Use in HTS Power Cables," Cryogenic Engineering Conference, Madison, July 2001.

2. J.E. Fesmire and S.D. Augustynowicz, "Insulation Testing Using Cryostat Apparatus With Sleeve," Advances in Cryogenic Engineering, Vol. 45, Kluwer Academic / Plenum Publishers, New York, 2000, pp. 1683-1690.

3. M.G. Kaganer, "Thermal Insulation in Cryogenic Engineering," Israel Program for Scientific Translations, Inc., IPST Press, Jerusalem, 1969, pp. 114-116.

4. S.D. Augustynowicz and J.E. Fesmire, "Cryogenic Insulation System for Soft Vacuum," Advances in Cryogenic Engineering, Vol. 45, Kluwer Academic/Plenum Publishers, New York, 2000, pp. 1691-1698.

5. J. A. Demko et al., "Practical AC Loss and Thermal Considerations for HTS Power Transmission Cable Systems," IEEE Transactions on Applied Superconductivity, Vol. 11, No. 1, 2001, pp. 1789-1792.

6. PHPK Technologies Inc., Westerville, Ohio USA, Vacuum Insulated Piping Catalog, 1997, p. 1.7. 